\title{
Etablering av et personentydig Norsk pasient- register: utdrag av høringsbrev og rapport
}

\author{
Inger Cappelen \\ Avdeling for helsestatistikk, Nasjonalt folkehelseinstitutt, Postboks 4404 Nydalen, 0403 Oslo \\ Telefon: 23408157 e-post: inger.cappelen@fhi.no
}

I mars 2004 oversendte Sosial- og helsedirektoratet en rapport til Helsedepartementet med tittel: "Personentydig norsk pasientregister. Forslag fra Sosial-og helsedirektoratet om etablering av Norsk pasientregister som et personentydig helseregister med hjemmel $i$ helseregisterloven." Fra Nasjonalt folkehelseinstitutt deltok avdelingsdirektør for Avdeling for helsestatistikk, Inger Cappelen i prosjektgruppen som utarbeidet rapporten, og Divisjonsdirektør Camilla Stoltenberg satt i styringsgruppen (oppnevnt av Helsedepartementet) for prosjektet.

Det påpekes imidlertid i selve rapporten at anbefalingene $\mathrm{i}$ den endelige rapporten helt og fullt er Sosialog helsedirektoratets alene. Dette er et viktig poeng fordi den videre prosessen forutsetter at Helsedepartementet fatter beslutninger, bl.a. på grunnlag av høringsuttalelser som skal avgis av blant annet virksomheter som har deltatt i prosessen. Sosial- og helsedirektoratet har derfor understreket at ingen andre virksomheter, organisasjoner eller enkeltpersoner har tatt endelig stilling til de forslag som direktoratet fremmer i denne rapporten.

Den 10. mai 2004 har Helsedepartementet sendt saken til høring, med høringsfrist 20. august 2004. (ref: http://odin.dep.no/hd/norsk/aktuelt/hoeringssaker/ paa_hoering/). Under denne saken finnes også hele rapporten i pdf-format. Vi vil oppfordre alle epidemiologiske miljøer om å engasjere seg og bidra med høringsuttalelser i favør av et personentydig Norsk pasientregister. Et personentydig register kan enten være pseudonymt eller personidentifiserbart. Folkehelseinstituttet går inn for et personidentifiserbart og kryptert register fordi dette gir bedre grunnlag for kvalitetssikring av data og validering av diagnoser, samtidig som det gir et bedre grunnlag for etablering av sykdoms- og/eller kvalitetsregistre som f.eks. et hjerteog karregister. Vi mener videre at et slikt register gir like godt personvern som et pseudonymt register.

Nedenfor følger noen utdrag fra departementets høringsbrev og fra selve rapporten fra Sosial- og helsedirektoratet.

\section{UTDRAG FRA HELSEDEPARTEMENTETS HØRINGSBREV}

Helsedepartementet sender med dette spørsmålet om opprettelse av et personentydig Norsk pasientregister
(NPR) på høring. Helseregistre reguleres av lov 18 . mai nr. 24 om helseregistre og behandling av helseopplysninger (helseregisterloven). Etablering av et personentydig NPR er utredet av Sosial- og helsedirektoratet. Direktoratet mener at det er tungtveiende grunner for å etablere NPR som et personidentifiserbart helseregister. Departementet skal på bakgrunn av direktoratets rapport og høringen ta stilling til hvorvidt det skal fremmes et forslag for Stortinget om å etablere NPR som et personidentifiserbart helseregister, eller om NPR skal opprettes som et pseudonymt helseregister.

\section{Formålet med horingen - horingsinstansenes syn på saerskilte områder}

Helsedepartementet ønsker nå en bred høring av Sosial- og helsedirektoratets forslag som bakgrunn for den videre behandling. Vi ber om høringsinstansenes syn på følgende områder:

1. Hvilke formål mener høringsinstansene Norsk pasientregister bør ivareta?

$\mathrm{Vi}$ ber om at høringsinstansene vurderer hvilke formål Norsk pasientregister ivaretar i dag, og om det er behov for å utvide formål og bruk av registeret $\mathrm{i}$ retning av nye forskningsmuligheter innen helse og helsetjenester, utvidet kvalitetssikring av helseopplysninger og forbedring og kvalitetssikring av behandlingsmetoder. Vi ber også om at høringsinstansene kommenterer om det er ønskelig å åpne for muligheten for å identifisere enkeltindivider i tilfeller der man avdekker særskilt høy sykdomsrisiko eller der man oppdager for eksempel feilbehandling eller skadevirkninger av behandling på grunnlag av registerdata.

2. Hva mener høringsinstansene om høringsrapportens forslag om etablering av et personidentifiserbart NPR med ekstern kryptering?

Vi ber om at høringsinstansene gir sitt syn på høringsrapportens forslag. Det er av særlig interesse å få synspunkter på $\mathrm{i}$ hvilken grad personverninteresser anses ivaretatt $\mathrm{i}$ hringsrapportens forslag.

3. Hvilken registerform er etter høringsinstansenes syn den som er best egnet, og ut fra hvilken begrunnelse?

På side 2 i dette høringsbrevet beskrives de fire alternativene - avidentifisert register, personidentifiserbart register basert på samtykke fra den enkelte pasient, pseudonymt register eller personidentifiserbart register 
uten samtykke. Vi ber høringsinstansene begrunne sitt valg.

Uavhengig av hvilken registerform som velges må det utarbeides en forskrift. I forskriften vil det gis nærmere bestemmelser om registeret og om behandling av helseopplysninger i registeret. En slik forskrift vil som vanlig måtte sendes på høring, og høringsinstansene vil da få anledning til å uttale seg mer konkret om registeret.

\section{UTDRAG FRA RAPPORTEN FRA SOSIAL- OG HELSEDIREKTORATET}

\section{Oppdraget}

Helsedepartementet ga i februar 2003 Sosial- og helsedirektoratet i oppdrag å gjennomføre et utredningsarbeid med sikte på å etablere Norsk pasientregister (NPR) som et personentydig register gjennom bruk av pseudonym eller pasientidentifikasjon. I henhold til prosjektbeskrivelsen skulle direktoratet vurdere om de eksisterende og eventuelt utvidete formålene med NPR, skissert i St.prp. nr. 1 (2002-2003) s. 142 og Semerklæringen kap. 11, best kan ivaretas innenfor et pseudonymt register, eller om formålene forutsetter et personidentifiserbart Norsk pasientregister.

I prosjektbeskrivelsen fra HD omtales oppdraget slik:

Oppdraget til SHDir er todelt:

1. Vurdere om de eksisterende og eventuelt utvidete formålene med NPR best kan ivaretas innenfor et pseudonymt register, eller om formålene forutsetter et personidentifiserbart Norsk pasientregister.

2. Avhengig av konklusjon på punkt 1, utarbeide forskrift (ved valg av pseudonymt register) eller forslag til lovendring (ved valg av personidentifiserbart register) som kan vedtas i hhv. statsråd eller Stortinget i løpet av vårsesjonen 2004.

Oppdraget innebærer å vurdere hvordan eksisterende og eventuelt utvidete formål best kan ivaretas og hjemles i helseregisterloven. De fire alternativene er: avidentifisert, personidentifiserbart med samtykke, pseudonymt, eller personidentifiserbart uten samtykke. De tre første registerformene krever hjemmel i forskrift, mens et personidentifiserbart register krever lovendring.

Rapporten utgjør den første delen av oppdraget, og er avgitt av Sosial- og helsedirektoratet. Anbefalinger og vurderinger i rapporten er dermed i tråd med direktoratets offisielle syn på de forhold som omtales.

\section{Begrepsavklaringer}

For å ha en felles forståelse av begrepene som benyttes i denne rapporten, gis innledningsvis en kort forklaring på de mest sentrale begrepene.

Avidentifisert betyr at navn, fødselsnummer og andre personentydige kjennetegn er fjernet, slik at opplysningene ikke lenger kan knyttes til en enkeltperson.
Bakveisidentifikasjon vil si å finne frem til pasientens identitet på bakgrunn av sammenstilling av opplysninger, selv om navn og fødselsnummer og andre direkte personidentifiserbare opplysninger er fjernet.

Personentydig innebærer at man kan koble flere opplysninger til samme individ til ulike tidspunkt. Dette kan gjøres pseudonymt eller personidentifiserbart.

Pseudonymt register: Identitet er kryptert eller skjult på annet vis, men likevel individualisert slik at det lar seg gjøre å følge hver person gjennom helsesystemet uten at identiteten røpes. Det skal ikke være mulig å gjenskape identiteten til den enkelte.

Personidentifiserbart register: Helseopplysninger følges av personopplysninger som navn og fødselsnummer inn til registeret.

Kryptert personidentifiserbart register: I registeret er det mulig å skille helseopplysninger og personopplysninger og kryptere personopplysningene, slik at disse bare kan leses med en bestemt nøkkel. Det innebærer at registeransatte som behandler helseopplysninger løpende ikke vil ha tilgang til den enkeltes identitet.

Det er også mulig å legge krypteringsfunksjonen til en ekstern part (Tiltrodd Pseudonymforvalter - TPF), slik det forutsettes gjort i pseudonyme registre. Den vesentligste forskjellen mellom et pseudonymt register og et kryptert, personidentifiserbart register, vil da være at man i det sistnevnte har mulighet for å gjenskape identitet hvis man har hjemmel for å behandle personidentifiserbare helseopplysninger.

\section{Bakgrunnen for rapporten}

Norsk pasientregister (NPR) ble formelt etablert i 1996 som en del av forberedelsene til ordningen med innsatsstyrt finansiering av somatiske sykehus (ISF). Norsk institutt for sykehusforskning hadde imidlertid siden 1987 hentet inn data om innleggelser fra norske sykehus som en del av arbeidet med å publisere sammenlignende statstikk for ressursbruk, aktivitet og effektivitet i sykehussektoren (SAMDATA Sykehus). NPR ble etablert som en viderutvikling av innleggelsesregisteret til SAMDATA sykehus, og etablert som et avidentfisert register med konsesjon fra Datatilsynet.

NPR er et sentralt helseregister og reguleres derfor av helseregisterloven. Bakgrunnen for dette arbeidet bygger på helseregisterloven og behovet for å gi NPR en forskriftsbasert hjemmel i tråd med loven. Helseregisterloven gir i prinsippet adgang til å opprette sentrale helseregistre som ikke er avidentifisert. Det innebærer at det $\mathrm{i}$ forbindelse med forankring av NPR i helseregisterloven må gjøres en vurdering av om NPR bør videreføres som et avidentifisert register, om det kan etableres som samtykkebasert eller pseudonymt register, eller om man bør foreslå for Stortinget å etablere NPR som et personidentifsert register.

\section{Registerets formål}

Spørsmålet om valg av registerform er nøye knyttet til registerets formål. 
Formålet med dagens NPR er å:

- Innhente, kvalitetssikre og arkivere virksomhetsdata fra norsk helsesektor.

- Legge datagrunnlaget til rette for forvaltning, forskning og offentlighet i tråd med retningslinjer gitt av Datatilsynet og registereier. Med virksomhetsdata forstås administrative og medisinske data om utførte behandlinger.

- Samordne og sammenstille data fra ventelister til behandling med virksomhetsdata.

NPR-data brukes blant annet som grunnlag for innsatsstyrt finansiering (ISF), SAMDATA-rapporter, ventetidsinformasjon i forbindelse med fritt sykehusvalg og formidling av nasjonale kvalitetsindikatorer. Dagens avidentifiserte registerform begrenser nytteverdien av NPR som informasjons- og planleggingsverktøy for spesialisthelsetjenesten og mulighetene for å kontrollere datakvaliteten.

Dagens formålsbeskrivelse legger hovedvekt på at det er forvaltning, forskning og offentlighet som skal være brukere av data fra NPR, mens det nevnes ikke hva denne informasjonen skal brukes til.

For at forvaltningen, forskere og offentligheten skal kunne følge opp helsepolitiske mål og pasientens interesser $\mathrm{i}$ forhold til rettferdig fordeling av helsetjenester av høy kvalitet, er det nødvendig å ha tilstrekkelig informasjon om tjenestene. NPR innehar et potensial til å bli et register med langt større nytteverdi enn i dag, både for forvaltningen, forskningen og pasientene. Dette krever at formålet utvides, og at det velges en registerform som understøtter formålet.

Sosial- og helsedirektoratet anbefaler derfor at NPR gis følgende formål:

NPR skal behandle data om behandlingsaktivitet i spesialisthelsetjenesten, som bidrag til informasjon om og hvordan tjenesten er i stand til å nå sine sentrale målsetninger, slik disse er definert i Spesialisthelsetjenesteloven. NPR skal ivareta pasientenes integritet og ikke krenke fortroligheten mellom den enkelte pasient og helsetjenesten. Basert på denne overordnede målsetningen skal registeret ha som formål å:

- Danne grunnlag for administrasjon, planlegging, styring og kvalitetssikring av spesialisthelsetjenesten og fordeling av helsetjenestens ressurser

- muliggjøre studier av pasientstrømmer mellom sykehus og over tid, samt analyser av sammenhenger mellom poliklinisk behandling, dagbehandling og innleggelser

- gi et beslutningsgrunnlag for struktur og funksjonsfordeling

- samordne og sammenstille data fra ventelister med virksomhetsdata

- fremme bruken av ensartede diagnostiske kriterier for gitte diagnoser

- bidra til overvåking av sykeligheten i befolkningen

- gi grunnlag for forskning for å utvikle ny viten om sykdommenes årsaker, diagnose, naturlige forløp og behandlingseffekter
- gi mulighet for kobling av data mot andre helseregistre, herunder overføring av relevante data for eksempel til Kreftregisteret og Medisinsk fødselsregister

- bidra til kvalitetssikring av innholdet i spesialisthelsetjenesten

- gi grunnlag for utvikling av kvalitetsindikatorer for styring, planlegging og fritt sykehusvalg.

\section{Gevinster ved personentydig register}

Det er innledningsvis pekt på den begrensede nytteverdien av dagens avidentifiserte register. Etter direktoratets vurdering, vil heller ikke et samtykkebasert register kunne ivareta ønskede formål, fordi det vil være inkomplett. Et NPR basert på samtykke eller avidentifisering gir ikke nødvendig grunnlag for vurdering av kvaliteten på helsetjenestene, bruk av ressurser i helsetjenesten, forekomst av sykdom i befolkningen, identifikasjon av årsaker til sykdom, eller holdbarheten i hypoteser som oppstår i media og i befolkningen om årsaker til sykdom.

I dag er det for eksempel ikke mulig å vite om fire tilfeller av diagnosen hjerteinfarkt gjelder fire ulike pasienter, eller fire infarkt hos samme pasient. Dersom en pasient behandles for samme diagnose på bare ett sykehus i løpet av ett år, vil man kan knytte diagnosen til samme pasient. Pasienter som får behandling for samme sykdom ved flere sykehus, eller får behandling som varer ut over ett kalenderår, vil imidlertid bli registrert som flere ulike pasienter. Det betyr at man verken kan bruke informasjon fra NPR til å informere om utbredelse av hjertesykdom, eller hvordan slik sykdom behandles:

- Vi vet ikke hvor mange mennesker som får hjerteinfarkt hvert år og blir innlagt i sykehus for dette

- Vi vet ikke hvor mange som får hjerteinfarkt for første gang i løpet av et år

- Vi vet ikke hvor mange som fikk sitt andre eller tredje hjerteinfarkt i fjor

- Vi kjenner ikke andelen som overlever sitt første hjerteinfarkt eller andelen som dør

- Vi vet ikke om overlevelsen er bedre for menn enn for kvinner

- Vi vet ikke om sannsynligheten for overlevelse er best ved store eller små sykehus

- Vi vet ikke om utfallet av behandling, inkludert følgene av hjertekirurgisk behandling, varierer mellom sykehus eller regioner fordi vi ikke kan vite om pasienten overlever etter utskriving fra sykehus

Vi har slike opplysninger for kreftsykdom. Pasienter med hjerte- og karsykdom har samme behov for kvalitetssikring av helsetilbudet de får, og forskning som kan klargjøre årsakene til sykdommen.

Den svenske Socialstyrelsen publiserer jevnlig analyser av behandlingskvalitet i svenske regioner/ kommuner og har vist at dødeligheten 30 dager etter hjerteinfarkt har gått ned og blitt mer lik i hele landet fra tidlig på 1990-tallet til sent på 1990-tallet. Dette 
skjedde etter at man begynte å publisere slik statistikk og ta den systematisk i bruk for å bedre behandlingen $(31,32)$.

Det er flere eksempler på hva vi ikke kan gjøre $\mathrm{i}$ Norge. For få år siden oppsto det en debatt om hvorvidt MMR-vaksine (spesielt meslingedelen av vaksinen) kunne være årsak til autisme. Debatten førte i Norge til en varig nedgang i vaksinasjonsdekningen for MMR-vaksine. Dette medfører en økt risiko for epidemier blant barn. Ved hjelp av en kobling mellom det danske pasientregisteret og vaksineregisteret kunne danske forskere etter meget kort tid vise at det ikke finnes holdepunkter for en slik sammenheng. På denne måten bidro danske registre vesentlig til å avkrefte en påstand som i seg selv medførte en økt helserisiko (33). Et personentydig pasientregister er et viktig middel for å raskt, sikkert og kostnadseffektivt tilbakevise eller styrke påstander om helsefarlige årsakssammenhenger. De nordiske land er av de få steder i verden der dette er mulig å gjøre.

Det vil være mange gevinster knyttet til forvaltning, styring og forskning ved at NPR gjøres personentydig. Ved å etablere NPR som et personentydig register, vil det blant annet gi mulighet for å følge pasientstrømmer, følge pasienter med kroniske lidelser og behov for langvarige tjenester, og bedre vurdering av behandlingseffekt. Det vil gi større muligheter for å kunne analysere sammenhenger mellom poliklinisk behandling, dagbehandling og innleggelse, og sist men ikke minst vil det gi mulighet for koblinger mot andre registre.

De ovennevnte gevinstene vil kunne hentes ut ved et pseudonymt register. Ved et pseudonymt register vil det imidlertid ikke være mulig å finne tilbake til enkeltpersoners identitet. Det betyr blant annet at:

- Det vil ikke være mulig å gå tilbake til kilden for å kvalitetssikre data

- Diagnostisk praksis kan ikke kontrolleres like effektivt

- Opprettelse og drift av kvalitetsregistre, særlig kvalitetssikring av innholdet, blir unødig tungvint og ressurskrevende. Forskningsresultater basert på NPR kan ikke kvalitetssikres, og dermed er det en fare for at forskningsresultater i mindre grad vil komme pasientene til gode i form av endret praksis

- Det vil ikke være mulig å benytte registeret som utgangspunkt for å anmode helsetjenesten om å følge opp enkeltpasienter som for eksempel har fått feilbehandling

Det avgjørende spørsmålet er derfor om merverdien av å etablere NPR som et kryptert, personidentifiserbart register, fremfor å etablere det som et pseudonymt register, er stor nok til å forsvare et forslag om lovendring. Dette må avveies mot konsekvensene for personvernet.

\section{Personvernet}

Hensynet til personvernet skal veie tungt når sensitive helseopplysninger skal samles inn, behandles og lagres. Lovverkets klare hovedregel er pasientens samtykke. Helseregisterloven legger likevel til grunn at det skal være mulig å opprette sentrale helseregistre med personidentifiserbare helseopplysninger uten pasientens samtykke, men at dette skal være gjenstand for en demokratisk prosess ved at det må vedtas i lovs form.

Sosial- og helsedirektoratet mener at NPR bør etableres som et kryptert, personidentifiserbart register, der pasientenes identitet ikke er tilgjengelig for personer som behandler helseopplysninger i NPR. Krypteringen av fødselsnummer bør legges til en ekstern part, slik at NPR ikke kan sammenstille identitet og personopplysninger. Hvordan dette konkret skal skje må reguleres i lov og forskrift.

Det bør være beskrevet $\mathrm{i}$ forskriften i hvilken grad og med hvilket formål en sammenstilling av identitet og helseopplysninger skal være tillatt. Formålet med sammenstillingen må være forenlig med registerets formål.

Sosial- og helsedirektoratet mener at den ovennevnte form for kryptering ivaretar pasientenes personverninteresser på en god måte. Det er derfor mulig å styrke pasientenes interesser med hensyn til bedre helsetjenester ved å etablere NPR som et kryptert, personidentifiserbart helseregister, uten at dette for sterkt kommer i konflikt med pasientenes interesser av et godt personvern.

Det kreves et særskilt hjemmelsgrunnlag for å sammenstille og utlevere opplysninger fra registeret. Helseopplysninger som er innmeldt i NPR kan sammenstilles med opplysninger $i$ andre sentrale, regionale eller lokale registre når dette er fastsatt i forskrift (helseregisterloven $\S 14, \S \S 12$ og 9). Det må være beskrevet i forskriften til de aktuelle registrene i hvilken grad slik sammenstilling kan skje og til hvilket formål.

Ved denne løsningen vil for eksempel Kreftregisteret kunne få tilgang til pasientens identitet. De som foretar løpende behandling av helseopplysninger i NPR vil imidlertid ikke ha tilgang til pasientens identitet.

Ved ekstern kryptering skjules pasientenes identitet i NPR, samtidig som man unngår pseudonymiseringens store ulempe med at det ikke er mulig å gå fra register til journal for å kvalitetssikre enkeltopplysninger.

For å imøtekomme målet om at sykehusene skal kunne tilby pasienter på venteliste raskere behandling, foreslås det å skille ut disse opplysningene i et eget samtykkebasert register, da dette først og fremst er i pasientenes egeninteresse.

\section{Arbeidsform}

Som det går frem av punktet ovenfor har Helsedepartementet bedt Sosial- og helsedirektoratet om en anbefaling om hvordan NPR skal forankres i helseregisterloven. Sosial- og helsedirektoratet har vært avhengig av en lang rekke bidrag og bidragsytere fra andre virksomheter $\mathrm{i}$ arbeidet med denne anbefalingen, men 
anbefalingen er like fullt direktoratets alene.

Dette er et viktig poeng fordi den videre prosessen forutsetter at Helsedepartementet fatter beslutninger, bl.a. på grunnlag av høringsuttalelser som skal avgis av blant annet virksomheter som har deltatt i prosessen. Sosial- og helsedirektoratet vil derfor understreke at ingen andre virksomheter, organisasjoner eller enkeltpersoner har tatt endelig stilling til de forslag som direktoratet fremmer i denne rapporten.

Likevel har arbeidet vært organisert med en prosjektgruppe knyttet til prosjektleder i direktoratet, med deltagelse fra Helsedepartementet, Nasjonalt folkehelseinstitutt og SINTEF Unimed. Departementet har også fulgt arbeidet gjennom en styringsgruppe som departementet har oppnevnt med medlemmer fra Helsedepartementets Eieravdeling, Folkehelseavdeling, Helserettsavdeling og Helsetjenesteavdeling. I tillegg har Sosial- og helsedirektoratet og Nasjonalt folkehelseinstitutt deltatt i styringsgruppen.

Sosial- og helsedirektoratet har i tillegg gjennomført to arbeidsseminarer. Ett med deltagelse fra forskningsmiljøer, helseregistre, Datatilsynet og professor Erik Boe. Og ett arbeidsseminar med de av pasientforeningene som er representert i Brukerforum for sykehusreformen. I tillegg har det vært holdt egne møter med Legeforeningen og Medisinsk fødselsregister. Det har vært holdt møter med Pasientregistrene i Danmark og Sverige, og problemstillingene har vært drøftet på et møte i Brukerforum for sykehusreformen.

De synspunkter og forslag Sosial- og helsedirektoratet har fått i denne dialogen har ikke vært entydige når det gjelder hva slags registerform som bør velges for NPR. Innspillene har likevel vært svært viktige for å få frem en nøktern og nyansert vurdering av de ulike alternativer, og for å få frem viktige momenter for den endelige vurderingen. Likevel står altså innholdet $\mathrm{i}$ denne rapporten for Sosial- og helsedirektoratets regning alene.

\section{Anbefaling}

Sosial- og helsedirektoratet anbefaler at NPR etableres som et kryptert, personidentifiserbart register. Krypteringen bør legges til en ekstern part. En slik løsning vil etter direktoratets syn være den beste måten å sikre pasientene lik tilgang til helsetjenester av høy kvalitet. De andre registeralternativene som helseregisterloven åpner for, vil redusere helsetjenestenes og helseforvaltningens mulighet til å sørge for at denne overordnede målsetning blir en realitet.

Den avgjørende forskjellen mellom et pseudonymt helseregister og det foreslåtte eksternt krypterte, personidentfiserte registeret, er muligheten til gå tilbake til kilden for å sikre datakvalitet. Samtidig skal kryptering sørge for at pasientenes identitet forblir skjult i selve registeret. Dermed vil pasientenes interesse av en god og rettferdig helsetjeneste styrkes vesentlig, samtidig som pasientenes interesse av et sterkt personvern blir ivaretatt på en god måte.
Anbefalingen gis etter en nøye gjennomgang av muligheter og begrensninger knyttet til de ulike løsningene, med utgangspunkt $\mathrm{i}$ en presisering av de formålene NPR bør ha. Forslaget ivaretar etter direktoratets syn både pasientenes interesser med hensyn til rettferdig fordeling av helsetjenester og best mulig kvalitet på tjenestene, ivaretakelse av individets integritet, et sterkt personvern og hensynet til samfunnets behov for informasjon.

Følgende momenter er spesielt vektlagt:

- NPR kan ikke etableres som et register basert på informert samtykke, eller som et avidentifisert register. Et norsk pasientregister basert på samtykke eller avidentifisering gir ikke grunnlag for vurdering av kvaliteten på helsetjenestene, bruk av ressurser $\mathrm{i}$ helsetjenesten, forekomst av sykdom i befolkningen, identifikasjon av årsaker til sykdom, eller holdbarheten i hypoteser som oppstår i media og i befolkningen om årsaker til sykdom. Sverige, Danmark og Finland bruker sine pasientregistre effektivt til slike formål i dag uten at det representerer en vesentlig trussel mot personvernet. Befolkningen i Norge har krav på slik informasjon og forskning. Norske helsemyndigheter og helsetjeneste har behov for slik informasjon for å kunne oppfylle sine forpliktelser i forhold til eksisterende lovverk. Det vil si at registeret bør være personentydig, enten pseudonymt eller personidentifiserbart.

- Innholdet i Norsk pasientregister (NPR) må fastslås i forskrift med utgangspunkt i registerets formål. NPR bør inneholde pasientens personnummer, opplysninger om diagnose, eventuelle hjelpebehov, tjenestetilbud, innskrivnings- og utskrivningsdato samt relevante administrative data. Ved en eventuell etablering av nasjonal ulykkesregistrering vil det også kunne være aktuelt å inkludere et minimum datasett knyttet til skader. NPR skal under ingen omstendighet inneholde opplysninger om pasientens sosiale forhold, livsstil og lignende. I den grad disse opplysningene eksisterer i dag, vil de bli slettet, og nye vil ikke bli registrert. Både pasientadministrative systemer (PAS) og elektroniske pasientjournalsystemer (EPJ-systemer) vil kunne avgi data til NPR.

- Kreftregisteret gir informasjon om forekomsten av kreftsykdom i befolkningen. Registeret brukes til å overvåke utviklingen av kreftsykdom og identifisere årsaker til kreft som kan gi bedre forebygging og behandling. Norge har i dag ikke tilsvarende informasjon for noen andre sykdomsgrupper. Vi kjenner for eksempel ikke til utbredelsen av hjerte- og karsykdom som er vår vanligste dødsårsak.

- For å kunne gå tilbake til kilden og validere kliniske forskningsresultater, må NPR være personidentifiserbart. Dette er av vesentlig betydning for kvalitetssikring av forskningsresultatene og dermed for forbedring av klinisk praksis.

- Et personidentifiserbart NPR kan også benyttes som datagrunnlag for eksisterende og nye kvalitets- og 
sykdomsregistre. Personidentifisering av NPR vil gi flere og bedre kvalitets- og sykdomsregistre, og dette vil være til stor fordel for pasientene. Et personidentifiserbart NPR er ikke den eneste, men etter vårt syn en kostnadseffektiv og god måte, å få flere slike registre på.

- NPR bør etableres som et eksternt kryptert personidentifiserbart register, der pasientenes identitet ikke er tilgjengelig for personer som behandler helseopplysninger i NPR. Det må være beskrevet i forskriften i hvilken grad og med hvilket formål en sammenstilling av identitet og helseopplysninger skal være tillatt, og formålet med sammenstillingen må være forenlig med registerets formål. Dette gjelder også sammenstilling med opplysninger $\mathrm{i}$ andre registre (helseregisterloven $\S 14, \S \S 12$ og 9).

- Den ovennevnte form for kryptering vil ivareta pasientenes personverninteresser på en god måte. Sosial- og helsedirektoratet mener at det derfor er mulig å styrke pasientenes interesser av bedre helsetjenester ved å etablere NPR som et personidentifiserbart og kryptert helseregister, uten at dette for sterkt kommer i konflikt med pasientenes interesser av et godt personvern.

På bakgrunn av det ovenstående foreslår rapporten at det bør fremmes et lovforslag om å endre helseregisterloven slik at loven gir hjemmelsgrunnlag for å etablere NPR som et kryptert personidentifiserbart helseregister, hvor krypteringen av fødselsnummer legges til en ekstern part.

\section{Sammendrag av rapporten}

I dette kapitlet gis et sammendrag av rapportens innhold, konklusjoner og anbefalinger. (I foreliggende utdrag fra rapporten er bare konklusjonen tatt med.)

\section{Konklusjon}

Sosial- og helsedirektoratet er bedt om å avgi en begrunnet oppfatning av hvordan NPR bør gjøres personentydig med hjemmel i helseregisterloven. Direktoratet har vurdert alle alternativer helseregisterloven gir for sentrale helseregistre, og funnet at personentydighet er viktig for et nasjonalt pasientregister som NPR. Videre har man vurdert hvilken betydning det har for pasientene, og dermed også for helsetjenesten, om NPR blir pseudonymt eller personidentifiserbart.

Direktoratet er kommet til at personidentifikasjon kan bidra til å gi pasientene bedre helsetjenester. Først og fremst fordi personidentifikasjon vil kunne gjøre eksisterende kvalitets- og sykdomsregistre bedre, samtidig som det vil bli enklere å opprette flere slike registre. Den endelige beslutning om hvorvidt fordelene ved flere og bedre kvalitets- og sykdomsregistre oppveier de personvernmessige ulempene ved personidentifisering, skal i følge helseregisterloven avgjøres av Stortinget.

I Innstilling O.nr. 62 (2000-2001) om lov om helseregistre uttalte Sosialkomitéen følgende:
Komiteen mener generelt at det skal stilles strengere krav til å godta opprettelse av et helseregister for forvaltningen enn for helsetjenesten. Fordi forvaltningens behov for informasjon ut fra ønsket om bedre forebyggingsstrategier egentlig ikke har noen grenser, kan $i$ prinsippet hele befolkningens livsførsel registreres. Etter komiteens oppfatning bør en derfor vare tilbakeholden med å opprette slike registre. Disse bør vare avidentifiserte eller pseudonymiserte slik at ingen risikerer at opplysninger om ens livsstil og livsførsel kommer på avveie.

Etter Sosial- og helsedirektoratets oppfatning er ikke spørsmålet i denne saken om NPR skal etableres som et personidentifiserbart helseregister for forvaltningen, men som et personidentifiserbart helseregister for helsetjenesten og pasientinteressene. For forvaltningens formål kan NPR meget godt være pseudonymt, men et pseudonymt NPR vil på et viktig område være et dårligere alternativ for helsetjenesten enn et personidentifiserbart register. I en tid hvor den medisinske fagkunnskapen er i rask utvikling, er det en allment akseptert oppfatning at det er viktig at helsetjenesten har gode verktøy i form av gode helseregistre for utvikling og kvalitetssikring av behandling ved alle sykehus. Et personidentifiserbart NPR kan bli viktig som et utgangspunkt for kvalitetssikring av etablerte helseregistre som Kreftregisteret og Nasjonalt register for leddproteser, og for etablering av nye helseregistre som det foreslåtte hjerte- og karregisteret. Et personidentifiserbart NPR kan dermed indirekte få stor betydning for faglig utvikling og kvalitetssikring av helsetjenesten.

Personidentifisering $i$ den form som er beskrevet $i$ denne rapporten er etter Sosial- og helsedirektoratets syn til fordel for pasientene. Dermed har vi en beslutningssituasjon som Sosialkomitéen beskrev på følgende måte i sin innstilling til ny helseregisterlov:

I den grad det er nødvendig ut fra hensynet til pasienten å benytte helseregistre med personidentifiserbare opplysninger, bør dette etter komiteens syn gjøres etter vedtak av Stortinget eller etter samtykke fra den registrerte. Ved å kreve Stortingsbehandling for slike registre etableres, sikres en demokratisk prosess som kan bidra til at nødvendige avveininger mellom hensynet til behovet for registre og hensynet til personvern foretas før vedtak treffes.

På denne bakgrunn, mener Sosial- og helsedirektoratet det er riktig at dette spørsmålet legges frem for Stortinget. Stortinget kan dermed foreta en konkret vurdering av om et kryptert, men i lovens forstand personidentifiserbart, Norsk pasientregister bør tillates etablert.

Sosial- og helsedirektoratet er også bedt om å vurdere om hensynet til en bedre helsetjeneste kan oppveie de ulemper som ligger $\mathrm{i}$ en personidentifisering av NPR. Direktoratet har ikke vurdert dette spørsmålet knyttet til et personidentifiserbart sentralt helseregister hvor pasientenes identitet ligger åpent, 
fordi det etter direktoratets oppfatning ikke er behov for et slikt register.

Derimot har Sosial- og helsedirektoratet vurdert etablering av NPR som et personidentifiserbart helseregister der personopplysningene er kryptert av en ekstern part og ikke tilgjengelig i selve registeret. En kryptert løsning vil ivareta personvernet på en god måte, fordi kryptering ikke skiller seg vesentlig fra pseudonymisering når det gjelder oppbevaring og tilgang til personidentifiserbare opplysninger $\mathrm{i}$ det sentrale registeret. Samtidig vil en krypteringsløsning bidra til at andre kvalitets- og sykdomsregistre blir bedre i stand til å ivareta sine funksjoner i tett dialog med den utøvende helsetjenesten. Kryptering vil i noen grad ivareta personverninteressene på samme måte som pseudonymisering, samtidig som en unngår de ulempene pseudonymisering av NPR vil ha for andre kvalitets- og sykdomsregistre.

Basert på denne vurderingen mener Sosial- og helsedirektoratet at NPR bør gjøres til et personidentifiserbart helseregister ved endring av helseregisterloven. I omtalen av NPR i loven bør det presiseres at NPR skal være kryptert av en ekstern part, slik det er beskrevet ovenfor. Formålet med registeret må både være å tjene som datagrunnlag om behandlingsaktivitet i spesialisthelsetjenesten for kvalitetssikring, forvaltning og forskning, og som datagrunnlag for andre personidentifiserbare helseregistre som drives i tråd med helseregisterloven. 